\title{
Terrestrial Gamma Radiation Dose Rate of West Sarawak
}

\author{
A. Izham, A.T. Ramli, W.M. Saridan Wan Hassan, H.N. Idris, N.A. Basri \\ Science Faculty, Universiti Teknologi Malaysia, Skudai, 81310. Johor Bahru, Malaysia
}

\begin{abstract}
A study of terrestrial gamma radiation (TGR) dose rate was conducted in west of Sarawak, covering Kuching, Samarahan, Serian, Sri Aman, and Betong divisions to construct a baseline TGR dose rate level data of the areas. The total area covered was $20,259.2 \mathrm{~km}^{2}$, where in-situ measurements of TGR dose rate were taken using $\mathrm{NaI}(\mathrm{Tl})$ scintillation detector Ludlum 19 micro $\mathrm{R}$ meter $\mathrm{NaI}(\mathrm{Tl})$ approximately 1 meter above ground level. Twenty-nine soil samples were taken across the 5 divisions covering 26 pairings of 9 geological formations and 7 soil types. A hyperpure Germanium detector was then used to find the samples, ${ }^{238} \mathrm{U},{ }^{232} \mathrm{Th}$, and ${ }^{40} \mathrm{~K}$ radionuclides concentrations producing a correction factor $C_{f}=0.544$. A total of 239 measured data were corrected with $C_{f}$ resulting in a mean $\mathrm{D} m$ of $47 \pm 1 \mathrm{nGy} \mathrm{h}^{-1}$, with a range between $5 \mathrm{nGy} \mathrm{h}^{-1}-103 \mathrm{nGy} \mathrm{h}^{-1}$. A multiple regression analysis was conducted between geological means and soil types means against the corrected TGR dose rate $\mathrm{Dm}$, generating $D_{G, S}=0.847 D_{G}$ $+0.637 D_{S}-22.313$ prediction model with a normalized Beta equation of $D_{G, S}=0.605 D_{G}+0.395 D s$. The model has an $84.6 \%$ acceptance of WhitneyMann test null hypothesis when tested against the corrected TGR dose rates.
\end{abstract}

\section{Introduction}

Humans are bombarded with natural gamma radiation daily (IAEA, 1989), originating from solar radiation and terrestrial gamma radiation of geological background and soil (UNSCEAR, 2000).

Radionuclides that have long half-lives that are formed during the formation of stars make up trace parts of today's geological background (Valkovic, 2000) contributing to varying levels of gamma radiation. These are naturally occurring radionuclides called primordial radionuclides. Although they exist in trace amounts in nature, the effects of gamma radiation over time may add up to cause stochastic effects (UNSCEAR, 2000).

This study focuses on terrestrial gamma radiation of west Sarawak, covering 5 divisions, Kuching, Samarahan, Serian, Sri Aman, and Betong, and explores the relationship between gamma radiation dose rates with geological background and soil types of the areas. 


\section{Research Methodology}

\section{Data Collection}

A total of 241 in-situ measurements were made in the study areas covering a total of 20,259.2 $\mathrm{km}^{2}$ :

- Kuching $\left(4,559.5 \mathrm{~km}^{2}\right)$

- Samarahan $\left(2,927.56 \mathrm{~km}^{2}\right)$

- Serian $\left(2,405 \mathrm{~km}^{2}\right)$

- Sri Aman $\left(6186.4 \mathrm{~km}^{2}\right)$

- Betong $\left(4,180.74 \mathrm{~km}^{2}\right)$

(Laman web rasmi Pentadbiran Bahagian Kuching, Pentadbiran Bahagian Samarahan, Majlis Daerah Serian, Pentadbiran Bahagian Sri Aman, Majlis Daerah Sri Aman, Jabatan Pertanian Sarawak, 2017).

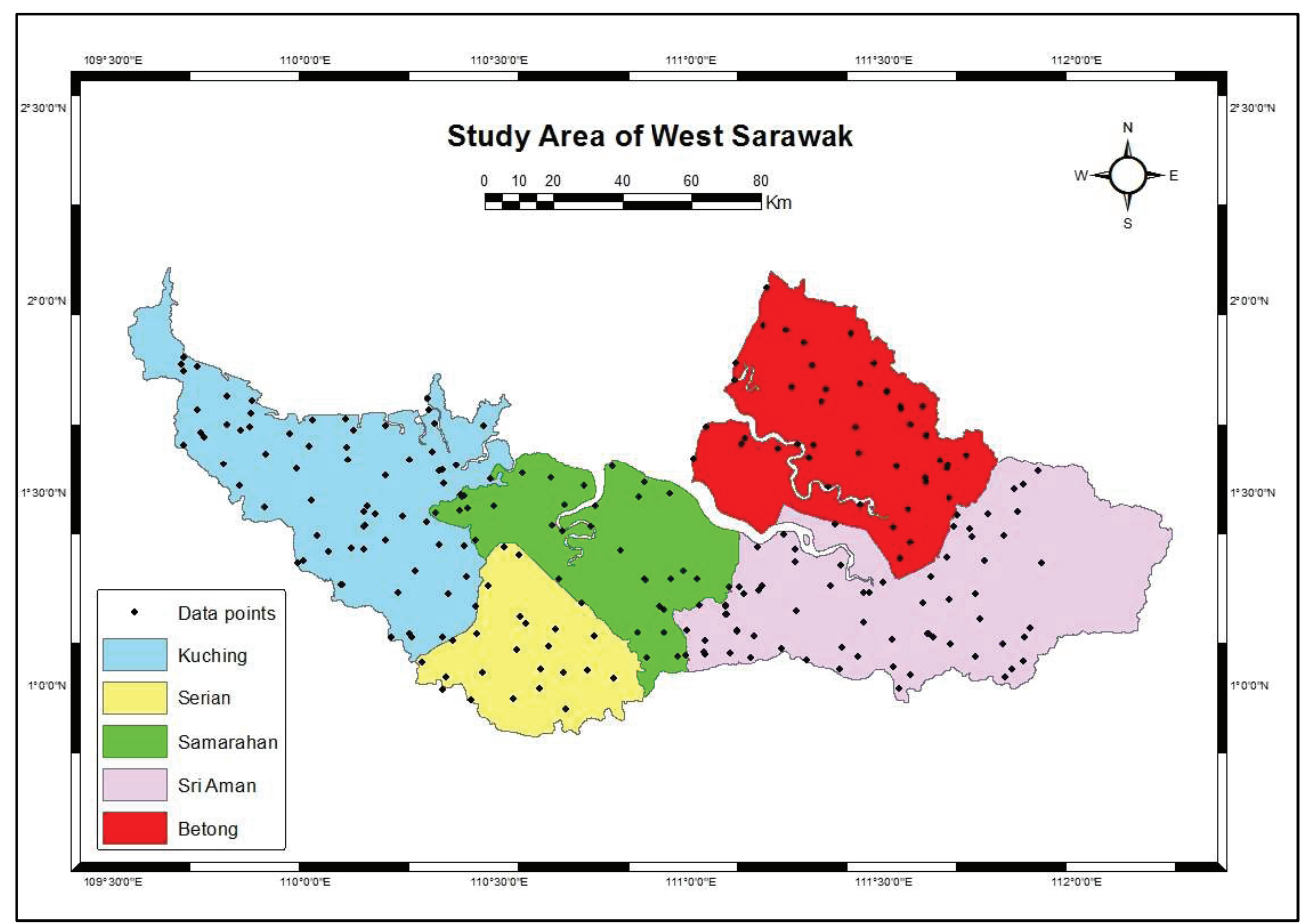

Fig 1. Study areas of west Sarawak, Kuching, Serian, Samarahan, Sri Aman, and Betong divisions and 241 terrestrial gamma radiation dose rate measurement locations (data points)

The dose rate readings were taken using a gamma radiation scintillation detector Ludlum $19 \mu \mathrm{R} \mathrm{h}^{-1}$ (micro Roentgen per hour). Sarawak map, (Directorate of National Mapping Malaysia, 2010), Sarawak geology map (Minerals and Geoscience Department Malaysia, 2013) and Sarawak soil map (Jabatan Pertanian Kuching Sarawak, 2008) were used to aid with random sampling method in consideration of geological background, soil distribution, and ease of access for data points selection. 


\section{Correction Factor}

Twenty-nine soil samples were taken throughout the 5 divisions and a Hyper-Pure Germanium detector at Science Faculty Universiti Teknologi Malaysia was used to examine their ${ }^{238} \mathrm{U},{ }^{232} \mathrm{Th}$, and ${ }^{40} \mathrm{~K}$ radionuclides content. The radionuclides concentration values were used to calculate terrestrial gamma radiation dose rates of the soil samples using the following equation (UNSCEAR, 2000):

$$
\mathrm{D}_{C}=0.462 \mathrm{C}_{238-\mathrm{U}}+0.604 \mathrm{C}_{232-\mathrm{Th}}+0.042 \mathrm{C}_{40-\mathrm{K}}
$$

where $\mathrm{D}_{C}$ is calculated gamma radiation dose rate, $\mathrm{C}_{238-\mathrm{U}}$ is ${ }^{238} \mathrm{U}$ radionuclide concentration, $\mathrm{C}_{232-\mathrm{Th}}$ is ${ }^{232} \mathrm{Th}$ radionuclide concentration, and $\mathrm{C}_{40-\mathrm{K}}$ is ${ }^{40} \mathrm{~K}$ radionuclide concentration.

Calculated dose rates $\mathrm{D}_{C}$ for the 29 samples were then compared to their respective insitu dose rate readings by linear regression to obtain a correction factor $C_{f}$ to be applied to all in-situ measurements producing corrected dose rates Dm (Sanusi, 2014).

\section{Prediction Model}

The relationship between geological formations and soil types of the study areas to the dose rates was explored. There are 9 geological formations and 7 soil types present in west Sarawak, with a total of 26 geology-soil pairings. The geological formations and soil types present in west Sarawak are as the following (Directorate of National Mapping Malaysia, 2010) :

Geological formations :
1. Igneous (G1)
2. Quaternary (G2)
3. Tertiary (G3)
4. Late Cretaceous - Miocene (G4)
5. Late Cretaceous (G5)
6. Late Jurassic - Late Cretaceous (G6)
7. Jurassic-Cretaceous (G7)
8. Triassic (G8)
9. Pre-Triassic / pre-Late Carboniferous (G9)

Soil types :
1. Alluvial and arenaceous (S1)
2. Gley (S2)
3. Podzolic (S3)
4. Organic (S4)
5. Skeletal (S5)
6. Podzol (S6)
7. Thionic (S7)

Mean dose rates for geological formations and soil types of west Sarawak were compiled and compared to dose rate readings of their respective corrected dose rates Dm. Multiple regression analysis was then conducted between corrected dose rates Dm, geological formations dose rates $\mathrm{D}_{G}$, and soil types dose rates $\mathrm{D}_{S}$ to find their respective contribution to the D $m$ dose rates (Tzortzis, 2002; Muneer, 2013; Sanusi, 2014). The resulting mathematical 
model was then applied to each data points and tested for statistical significance against $\mathrm{Dm}$ using Whitney-Mann test.

\section{Results and Analysis}

\section{Data}

To obtain data normality, 2 outliers were excluded from the 241 collected dose rate readings. The calculated dose rate $\mathrm{D}_{C}$ from equation (2.1) of the 29 samples were then compared to their respective in-situ dose rate readings, producing a correction factor $C_{f}=0.544$ from a linear fitting of $\mathrm{y}=0.544 \mathrm{x}+8.13$. This correction factor $C_{f}$ was then applied to the remaining 239 dose rate readings. Mean corrected dose rate reading $\mathrm{D} m$ is $47 \pm 1 \mathrm{nGy} \mathrm{h}^{-1}$ with a range between $5 \mathrm{nGy} \mathrm{h}^{-1}-103 \mathrm{nGy} \mathrm{h}^{-1}$.

The distribution is deemed normal due to its acceptable histogram trendline from Figure 2 , skewness of 0.469 , and kurtosis of 0.263 .

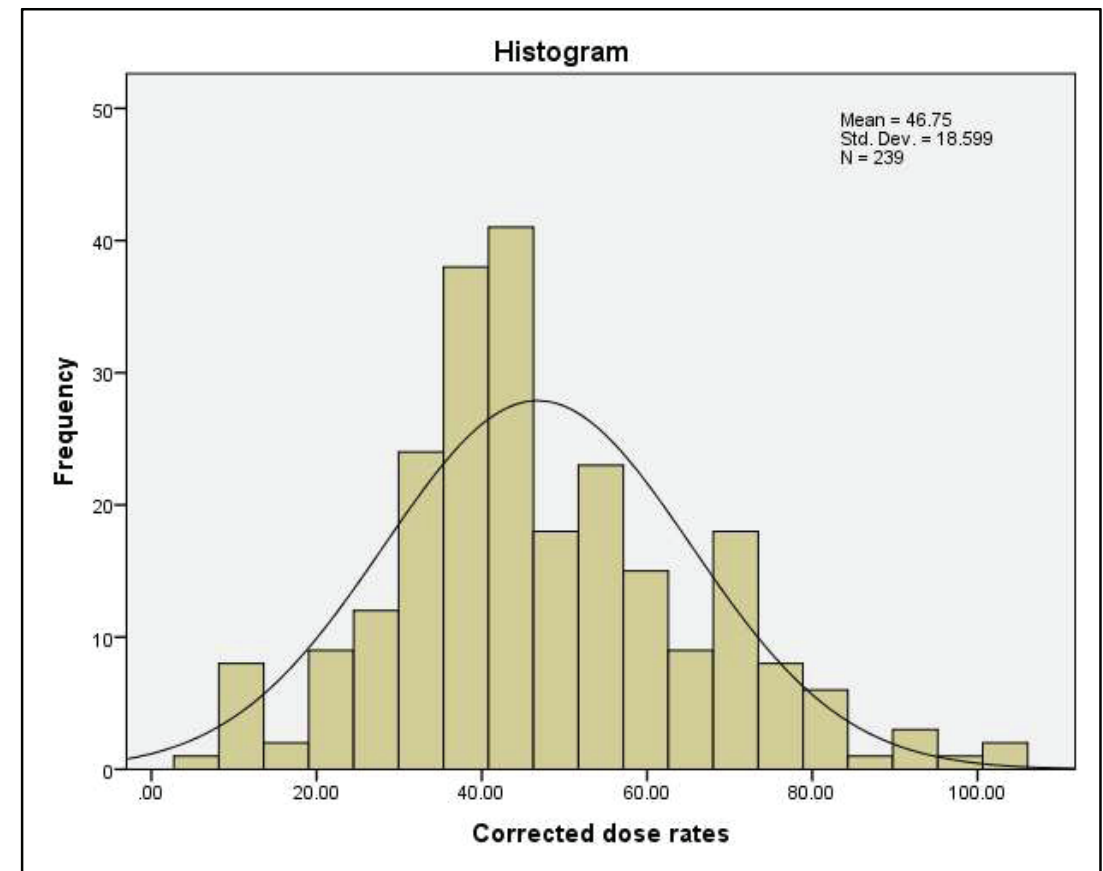

Fig 2. Histogram of corrected dose rates with trendline

\section{Prediction model}

A multiple regression of geological formation dose rates, soil types dose rates, and corrected dose rates generates the equation:

$$
\mathrm{D}_{G, S}=0.847 \mathrm{D}_{G}+0.637 \mathrm{D}_{S}-22.313
$$

The normalized Beta coefficient equation is:

$$
\mathrm{D}_{G, S}=0.605 \mathrm{D}_{G}+0.395 \mathrm{D}_{S}
$$


This prediction model (3.1) is applied to all 26 pairs of geology-soil pairings and the comparison of geology-soil pairing predicted dose rates to the corrected dose rates $\mathrm{D} m$ and Whitney-Mann test of the comparisons are as in Table 1.

Table 1. Comparisons of geology-soil pairing predicted dose rates $\left(\mathrm{D}_{G} \cap \mathrm{D}_{S}\right)$ to corrected dose rates $\mathrm{D} m$ and their respective Whitney-Mann test $\mathrm{p}$-values.

\begin{tabular}{|c|c|c|c|c|c|}
\hline $\mathrm{D}_{G}$ & $\mathrm{D}_{S}$ & $\begin{array}{c}\text { Corrected } \\
\text { dose } \mathrm{D} m\end{array}$ & $\begin{array}{c}\text { Predicted } \\
\mathrm{D}_{G} \cap \mathrm{D}_{S}\end{array}$ & $\begin{array}{l}\text { Whitney- } \\
\text { Mann test } \\
\text { p-value }\end{array}$ & $\begin{array}{l}\text { Null test } \\
\text { decision }\end{array}$ \\
\hline G1 & $\mathrm{S} 3$ & 40 & 48 & 0.013 & rejected \\
\hline G1 & S5 & 57 & 55 & 0.367 & accepted \\
\hline $\mathrm{G} 2$ & $\mathrm{~S} 2$ & 40 & 40 & 0.519 & accepted \\
\hline $\mathrm{G} 2$ & $\mathrm{~S} 3$ & 40 & 41 & 0.224 & accepted \\
\hline $\mathrm{G} 2$ & $\mathrm{~S} 4$ & 37 & 36 & 0.113 & accepted \\
\hline G2 & S5 & 60 & 49 & 1.000 & accepted \\
\hline G2 & S7 & 39 & 36 & 0.699 & accepted \\
\hline G3 & $\mathrm{S} 2$ & 37 & 45 & 0.102 & accepted \\
\hline G3 & $\mathrm{S} 3$ & 46 & 46 & 0.071 & accepted \\
\hline G3 & $\mathrm{S} 4$ & 30 & 41 & 0.487 & accepted \\
\hline G3 & S5 & 50 & 54 & 0.039 & rejected \\
\hline G4 & S3 & 34 & 38 & 0.163 & accepted \\
\hline G4 & $\mathrm{S} 5$ & 43 & 47 & 0.577 & accepted \\
\hline G5 & $\mathrm{S} 2$ & 60 & 61 & 1.000 & accepted \\
\hline G5 & $\mathrm{S} 3$ & 62 & 62 & 0.581 & accepted \\
\hline G5 & S4 & 49 & 57 & 0.102 & accepted \\
\hline G5 & S5 & 71 & 70 & 0.222 & accepted \\
\hline G6 & S3 & 39 & 40 & 0.247 & accepted \\
\hline G6 & S5 & 35 & 48 & 0.037 & rejected \\
\hline G7 & S3 & 41 & 47 & 0.033 & rejected \\
\hline G7 & S5 & 51 & 55 & 0.102 & accepted \\
\hline G8 & $\mathrm{S} 2$ & 57 & 54 & 1.000 & accepted \\
\hline G8 & S3 & 56 & 54 & 1.000 & accepted \\
\hline G8 & S4 & 45 & 49 & 1.000 & accepted \\
\hline G8 & S5 & 64 & 63 & 0.487 & accepted \\
\hline G9 & S3 & 44 & 45 & 0.094 & accepted \\
\hline
\end{tabular}

From a total of 26 pairings, 22 pairs shows accepted (p-value more than 0.05) WhitneyMann null test hypothesis. This $84.6 \%$ acceptance signify statistically significant relationship between geological formation and soil types to TGR dose rates. 


\section{Conclusion}

From a total of 241 initial measurements taken, 2 outliers were excluded, leaving 239 terrestrial gamma dose rate readings corrected with $C_{f}=0.544$, obtained from linear fitting between measured dose rates and calculated dose rates of 29 soil samples taken. Mean corrected dose rate reading $\mathrm{D} m$ is $47 \pm 1 \mathrm{nGy} \mathrm{h}^{-1}$ with a range between $5 \mathrm{nGy} \mathrm{h}^{-1}-103 \mathrm{nGy}$ $\mathrm{h}^{-1}$. This value is lower than the world average of $59 \mathrm{nGy} \mathrm{h}^{-1}$ (UNSCEAR, 2000) and much lower than terrestrial gamma dose rates of peninsular Malaysia (165 $\mathrm{nGy} \mathrm{h}^{-1}$ for Johor, 172 $\pm 17 \mathrm{nGy} \mathrm{h}^{-1}$ for Melaka, $222 \pm 191 \mathrm{nGy} \mathrm{h}^{-1}$ for Kinta, Perak, $176 \pm 5 \mathrm{nGy} \mathrm{h}^{-1}$ for Pahang, and $182 \pm 81 \mathrm{nGy} \mathrm{h}^{-1}$ for Selangor) (Ramli, Hussein, 2001; Lee et al, 2009; Gabdo et al, 2013; Sanusi et al, 2014). A prediction model of geological formation and soil types contribution to the dose rate readings was generated, producing the equation $\mathrm{D}_{G, S}=0.847 \mathrm{D}_{G}+0.637 \mathrm{D}_{S}-$ 22.313 with a normalized Beta coefficient equation of $\mathrm{D}_{G, S}=0.605 \mathrm{D}_{G}+0.395 \mathrm{D}_{S}$, translating to $60.5 \%$ contribution from geological background and $39.5 \%$ contribution from soil types to dose rates. When applied to geology-soil pairings of the study area, the prediction model produces an 84.6\% Whitney-Mann acceptance level when tested against corrected dose rate readings, indicating statistically significant relationship between geological formation and soil types to terrestrial gamma dose rates. Thus, the prediction model can be used to predict terrestrial gamma radiation dose rate for areas with similar geology-soil pairing profile across Sarawak.

\section{References}

1. A. T. Ramli, A. W. Hussein, (2001). Geological influence on terrestrial gamma radiatio dose rate in the Malaysian State of Johore. Applied Radiation and Isotopes 54, 327-333.

2. Directorate of National Mapping Malaysia, (2010). Sarawak Map, edisi 1-PPNM, Director of National Mapping Malaysia. Jabatan Ukur dan Pemetaan Malaysia, Kuala Lumpur.

3. H. T. Gabdo, A. T. Ramli, M. S. Sanusi, M. A. Saleh, N. N. Garba (2013). Terrestrial gamma dose rate in Pahang state Malaysia. Journal of Radioanalytical and Nuclear Chemistry 299, Issue 3, 1793-1798.

4. International Atomic Energy Agency (IAEA), (1989). Measurement of Radionuclides in Food and the Environment, A Guidebook. Technical Reports Series No. 295. International Atomic Energy Agency, Vienna.

5. Jabatan Pertanian Kuching Sarawak, (2008). Kumpulan Utama Tanah Sarawak, GIS Cawangan Pengurusan Tanah. Jabatan Pertanian Kuching Sarawak, Sarawak.

6. Jabatan Pertanian Sarawak, (2017, July 14). Betong Divisional Agriculture Office. Retrieved July 14, 2017, from http://www.doa.sarawak.gov.my.

7. M. S. M. Sanusi, A. T. Ramli, H. T. Gabdo, N. N. Garba, A. Heryanshah, H. Wagiran, M. N. Said, (2014). Isodose mapping of terrestrial gamma radiation dose rate of Selangor state, Kuala Lumpur, and Putrajaya, Malaysia. Journal of Environmental Radioactivity $135,67-74$.

8. Majlis Daerah Serian, (2017, July 14). Sejarah kami. Retrieved July 14, 2017, from http://www.seriandc.sarawak.gov.my.

9. Majlis Daerah Sri Aman, (2017, July 14). Pengenalan. Retrieved July 14, 2017, from http://www.sriamandc.sarawak.gov.my.

10. Minerals and Geoscience Department Malaysia, (2013). Geological map of Sarawak, third edition, Director General of Minerals and Geoscience Department Malaysia. Minerals \& Geoscience Department Malaysia, Kuala Lumpur.

11. Pentadbiran Bahagian Kuching, (2017, July 14). Sejarah Kuching. Retrieved July 14, 2017, from http:/www.kuching.sarawak.gov.my. 
12. Pentadbiran Bahagian Samarahan, (2017, July 14). Profil Bahagian Samarahan. Retrieved July 14, 2017, from http:/www.samarahan.sarawak.gov.my.

13. Pentadbiran Bahagian Sri Aman, (2017, July 14). Profil Daerah Lubok Antu. Retrieved July 14, 2017, from http://www.sriaman.sarawak.gov.my.

14. S. K. Lee, H. Wagiran, A. T. Ramli, N. H. Apriontoro, A. K. Wood, (2009). Radiological monitoring: terrestrial natural radionuclides in Kinta District, Perak, Malaysia. Journal of Environmental Radioactivity 100, 368-374.

15. United Nations Scientific Committee on the Effects of Atomic Radiation (UNSCEAR), (2000). Sources, effects, and risks of ionization radiation. Report to the General Assembly, with Scientific Annexes B: Exposures from Natural Radiation Sources. United Nations, New York.

16. Vlado Valkovic, (2000). Radioactivity in environment, Elsevier Science B.V., Amsterdam. 